\title{
DESIGNING E-LEARNING IN MEDICAL EDUCATION: TOWARD A COMPREHENSIVE MODEL
}

\author{
Dr. Soleiman AHMADY \\ ORCID: 0000-0003-0551-6068 \\ Faculty of Medical Education \\ Shahid Beheshti University of Medical Sciences \\ Tehran, IRAN
}

Dr. Zohrehsadat MIRMOGHTADAIE

ORCID: 0000-0002-3267-9121

Faculty of e-learning in Medical Education Shahid Beheshti University of Medical Sciences

Tehran, IRAN

Dr. Nahid ZARIFSANAIEY

ORCID: 0000-0002-1297-8271

Faculty of e-learning in Medical Education

Shiraz University of Medical Sciences

Shiraz, IRAN

Dr. Johan THOR

ORCID: 0000-0003-1814-4478

School of Health and Welfare

University of Jonkoping Jonkoping, SWEDEN

Received: 08/05/2019 Accepted: 08/01/2020

\begin{abstract}
This study was conducted to present a comprehensive model for designing e-learning in Medical education. This qualitative study was performed in three stages. First, we used the "critical review" approach proposed by CarnWell to synthesize a conceptual model from studies that employ e-learning in Medical education. In the second stage, using Bereday's comparative method, 30 renowned virtual universities were evaluated. Finally, after aggregating and summarizing the results of the previous stages, the model was presented.

The results of the study showed that designing e-learning in medical education requires making plans on national and international levels. Moreover, for qualitative and quantitative improvement of e-learning, global progress, achievements, and standards should be monitored continuously, and strategic, tactical, and executive aspects should be rigorously addressed. This comprehensive model for the design and development of e-learning in medical education is identified as an area requiring further research.
\end{abstract}

Keywords: e-Learning, medical education, qualitative method, design, critical review.

\section{INTRODUCTION}

E-learning is an essential innovation in medical education which has expanded the boundaries of learning beyond regional and national borders to global frontiers by breaking down the barriers of time and place (Gaupp, Korner, \& Fabry, 2016). E-learning can enhance the quality and accessibility of educational opportunities for different people by providing learning conditions that help them overcome traditional time 
and place constraints. It enables learners to develop new competencies and to earn valid scientific degrees and certificates. Experts believe that e-learning has become an essential modality in medical education (De Leeuw, Westerman, Nelson, Ket, \& Scheele, 2016).

The ever-growing emphasis on the benefits of e-learning in medical education has increased the demands for virtual courses and workshops in universities' curriculums (Aboshady et al., 2015). According to Allen \& Seaman (2013), online courses in educational institutions are increasing day by day in the United States. Universities across the world have made considerable efforts to implement e-learning; it is estimated that by $2025,85 \%$ of education will be delivered electronically (Cidral, Oliveira, Di Felice, \& Aparicio, 2018). E-learning increases the efficacy and effectiveness of medical education which explains why e-learning is increasingly utilized by medical schools around the world. To develop e-learning programs, it is critical to have a clear theoretical framework for their design, especially in medical education (Frehywot et al., 2013).

Designing e-learning in medical education requires attention and consideration of all the essential aspects of this environment. Thus, a comprehensive model is needed to help stakeholders capture the critical dimensions of this context. Consequently, this study was conducted to develop a comprehensive model for e-learning in medical education.

\section{LITERATURE REVIEW}

In the information age, the process of globalization has introduced a new paradigm in human learning, and universities increasingly seek to harness the benefits of emerging technologies in their educational activities (Ruggie, University, USA, University, \& USA, 2017). Research has shown that using e-learning in medical education has increased in recent decades (Salimi, Mohammadi, \& Hosseini, 2017). There are two major uses of information and communication technology in medical education, one is to improve access to educational resources and the other is to enhance collaboration and communication between teachers and learners (Amin, Joo, \& Jamali, 2018). According to some researches, E-learning can help with the personalization of the learning environment, a wide distribution of learning materials and resources, content standardization, improvement of the knowledge acquisition process, and basic and clinical skills. E-learning provides opportunities for flexible learning. It also provides the possibility of self-regulation in the learning process (Bello, Oludele, \& Ademiluyi, 2018). Concerning the importance of e-learning in medical sciences, international organizations such as the United Nations and the World Health Organization emphasize that e-learning is a useful way of addressing educational needs in medical education (Ellaway \& Masters, 2008).

E-Learning can fill the gap between theory and practice and it can encourage the learner to solve problems and exchange experiences. Having a profound understanding of these developments, medical universities all over the world are seeking to develop optimal methods and models for implementing effective e-Learning(Gaupp et al., 2016). For this reason, several diverse factors may determine the success of an e-learning system. Indeed, for designing any system, moving toward a particular model or framework will lead to systematic work and secure better results. This also applies to designing e-learning systems. Consulting a specifically defined framework can determine e-learning system requirements, and make it easier to design (Aithal \& Aithal, 2015).

Numerous studies have been conducted on designing models and frameworks for e-learning in higher education. For example, Namisiko, Munialo, \& Nyongesa (2014) concluded that a systematic and comprehensive approach to e-learning depends on at least three fundamental conditions: 1) simultaneous and continuous attention to all educational, technical, and organizational aspects of the learning environment, 2) presence of a systematic viewpoint for designing an educational system, and 3) learner-centeredness of the e-learning system.

Meltzer ( 2018) also believes that an e-learning framework requires the establishment of at least three necessary conditions; constant attention to all educational, technical, and organizational dimensions of the learning environment, and careful consideration of the pervasive features of an electronic learning system.

Also, in their study Haddad \& Draxler (2002) outline seven aspects that are necessary for the success of an e-learning system: educational policy, approach, infrastructure, content ware, committed and trained personnel, financial resources, and integration. This learning environment facilitates interaction and creates 
a conceptual framework through the use of multimedia and contributes to active knowledge acquisition by learners.

One of the most crucial prerequisites for the successful implementation of e-Learning is a careful deliberation of the underlying pedagogy, or how learning takes place online. In this regard, Aboumatar et al. (2012)selfefficacy and system thinking. Methods: This study reports on curriculum development and evaluation of a 3-day, clinically oriented patient safety intersession that was implemented at the Johns Hopkins School of Medicine in January 2011. Using simulation, skills demonstrations, small group exercises and case studies, this intersession focuses on improving students' teamwork and communication skills and systembased thinking while teaching on the causes of preventable harm and evidence-based strategies for harm prevention. One hundred and twenty students participated in this intersession as part of their required second year curriculum. A preepost assessment of students' safety knowledge, selfefficacy in safety skills and system-based thinking was conducted. Student satisfaction data were also collected. Results: Students' safety knowledge scores significantly improved (mean $+19 \%$ points; $95 \%$ CI 17.0 to 21.6 ; $\mathrm{p}<0.01$ proposed a model for designing virtual universities. According to this model, the learning environment should prepare the grounds for genuine learning activities, reinforce the learners' sense of responsibility for learning, encourage participation, and employ authentic assessment strategies.

Garrison (2011), analyzed the theoretical challenges of distance education in the 21 st century. He designed a conceptual model for distance education, knows as the "community learning model." According to this model, any effective educational experience requires social, cognitive, and teaching presence. Social presence is defined as the ability of the online teacher to provide a learning environment in which learners communicate with each other openly and securely. Cognitive presence indicates that the online teacher should create an appropriate environment to develop the learners' basic thinking skills. Teaching presence emphasizes the effective design of the learning environment based on technology. As can be seen, the important aspects of the learning environment need to be taken into account when designing appropriate models.

In this respect, globalization and the emergence of information technologies, and contemporary developments have resulted in rapid changes in medical education (Franz, Behrends, Haack, \& Marschollek, 2015). There has also been growing interest in the use of e-learning in medical universities. The shift towards e-Learning, the complexity of medical education, and the advances in medicine have all increased the demands for using information and communication technology in medical education(Fernandez-Rodriguez, 2017). Despite the increasing use of e-learning in medical education, research on this topic is in its early stages. Existing research mostly covers the design and implementation of e-learning in different medical disciplines. No studies have yet investigated the design of e-learning models and frameworks in medical education in a systematic fashion(Lewis, Cidon, Seto, Chen, \& Mahan, 2014).

The most important challenge in designing and launching e-learning in medical education is to disregard all the important aspects that constitute a learning environment that can take into account the complexities of the clinical and educational environment in design(Ikram, Essink-Bot, \& Suurmond, 2015b)care providers tend to underuse professional interpretation. Evidence suggests that students who received training on language barriers and interpreter use are more likely to utilize interpretation services. Aims: We developed an e-learning module for medical students on using professional interpreters during the medical interview, and evaluated its effects on students' knowledge and self-efficacy. Methods: In the e-learning module, three patient-physician-interpreter video vignettes were presented, with three different types of interpreters: a family member, an untrained bilingual staff member, and a professional interpreter. The students answered two questions about each vignette, followed by feedback which compared their responses with expert information. In total, 281 fourth-year medical students took the e-learning module during the academic year 2012-2013. We assessed their knowledge and self-efficacy in interpreter use pre- and post-test on 1 (lowest. One of the essential issues in this regard is the presence of proper patterns or designing models that are consistent with medical education.

Given the conflicting results in previous studies, there is still a need for further research in this field, particularly since facilities and methods are constantly transformed. In designing an appropriate model and framework for e-learning in medical education, all aspects of a medical education environment should be taken into account Therefore, it seems necessary to present a comprehensive model for e-learning in medical 
education. Following the above argument, researchers decided to research designing a comprehensive model of e-Learning in medical education.

The specific objectives of this research were as follows:

1. To determine the key design components of e-learning in medical education

2. To identify and compare the components of e-learning programs in renowned universities across the world

3. To present a comprehensive model for e-learning in medical education

\section{METHOD}

\section{Study Design}

The goal of this study is to achieve some degree of innovation and synthesis. This is a qualitative study; in terms of method it is heuristic, in terms of the period it is cross-sectional, and in terms of purpose it is developmental; a particular approach has been used at each stage.

\section{The First Stage}

The first stage was conducted using the critical literature review approach in which the aim and scope of the review were outlined. On this basis, the relevant literature was identified and selected using exclusion and inclusion criteria. The study addresses a focused question: What evidence is available about the main e-learning concepts in medical education?

We critically reviewed selected research reports about the deployment of e-learning models in medical education and their concepts. Our review relies on (Carnwell \& Daly, 2001)\& Daly's (2001) 'critical review' approach to literature synthesis. A critical review aims to evaluate the relevance and thoroughness of available research in terms of the theoretical framework. The objective of the critical review is to qualitatively summarize research findings and compare the similarities and differences of different studies. Furthermore, the context of the studies is investigated to identify what makes educational interventions work qualitatively. At this stage, we: 1) focused on the main concepts of e-learning in medical education, 2) Identified sources of relevant information, and 3) reviewed the literature and applied findings in drafting the e-learning model.

Samples and setting: We searched multiple databases (Google Scholar, Scirus, ProQuest, Scopus, IEEE, SID, Bio-Medical, PubMed, Medline (EBSCO \& Ovid), Eric, Taylor and Francis, and Science Direct) and also examined reference lists of highly cited papers and reviewed articles from 2000 to 2018 . The keywords used for the search were (electronic OR virtual OR Online OR Internet-based OR distance OR web-based) AND (medical, health) AND (learning OR instruction OR education) AND design AND Development.

Participant characteristics: To select the documents, the titles found in the search engine were first evaluated for relevance. The retrieved material was divided into three categories of websites, books, and articles. Articles were excluded if they were not written in English or Farsi, or if they did not involve education in health professions. We included a full review of all original research studies involving e-learning in medical education.

Analysis: This approach yielded 142 articles published between 2000 and 2019. On initial assessment, the titles and abstracts were selected by two reviewers, and documents with less relevance to the research topic were excluded. The articles retrieved by the searches were sorted by each of the investigators into two groups: primary publications (reports of studies that produced original data) and secondary publications (those not producing original data, such as literature reviews, editorials, and letters). In the next step, the primary publications about e-learning in the fields of medicine and health were classified by each of the investigators into three types of study, termed observational studies, pragmatic studies, and explanatory studies.

A total of 87 Farsi and English articles, which were more valid and compatible with the general objective of the study, were selected and meticulously evaluated. We extracted information from each paper into a spreadsheet and used the constant comparison method to explore possible topics of e-learning and Medicine. We independently analyzed the definitions and identified recurrent topics using "coding." As described by 
Strauss and Corbin, coding is an analytical process through which concepts are identified and dimensions are discovered in data (Willcocks, Sauer, \& Lacity, 2016).

\section{The Second Stage}

In the second stage, to achieve a more in-depth understanding, the components and the structures of successful e-learning systems in renowned universities across the world were evaluated using Bereday's comparative method. This method is one of the most important classical methods for comparing educational systems. According to the Bereday model, comparative studies should employ well-known and wellstudied instructional methods. In this stage, the researchers examined and compared the structure and the components of the e-learning systems at selected universities across the world using Bereday's four-step method, including description, interpretation, juxtaposition, and comparison (Adick, 2018).

At the description stage, information and evidence about the e-Learning systems of the selected universities in three continents were obtained. Thus, sufficient material was available for review and critique in the next stage. Detailed information was gathered according to the following criteria:

1. Availability of e-Learning for students in various degrees and levels of study,

2. Student admission criteria,

3. Teaching-Learning approach,

4. Evaluation methods,

5. E-learning Infrastructures.

In the interpretative phase, the detailed information obtained regarding the e-learning systems of the selected universities was investigated and analyzed. In the juxtaposition phase, the information and analyses collected in the previous stages were categorized and integrated to develop a clear framework for the comparison of their similarities and differences. Finally, at the fourth stage (comparison), details of the similarities and differences of the e-learning systems of the selected universities were compared to address the research questions.

Samples and setting: Purposive sampling was performed according to the classification proposed by Ambient Insight market research firm. It is an international market research firm that uses quantitative predictive analytics to identify revenue opportunities for advanced global learning technology suppliers (Agarwal \& Lenka, 2018)garment industry and educational institute. Those virtual universities in North America, Europe, Australia, and Asia that had the highest ranks in the Ambient classification in 2014, and whose information was available on their websites, were included in the study. Accordingly, 30 credible universities were selected, and their e-learning systems were studied.

In North America; University of Pennsylvania, Yale University, The University of Chicago, Johns Hopkins University, Princeton University, University of California, Duke University, Cornell University, University of British Columbia, University of Bristol, McGill University, University of Toronto, and Northwestern University were assessed. In Europe; the e-learning systems of the universities of Austria, King's College, Federal Of Technology, ETH Zurich University, Techniches Universität in Germany; Ecole Normale Superieure in France, the University of Edinburgh in Scotland, Manchester University, Swiss Federal University, Uppsala University of Sweden and Utrecht University in the Netherlands were investigated. In Asia, the e-learning systems of the universities of Nanyang Technological University in Singapore, National University of Singapore, Tsinghua University in China, The University of Hong Kong, Seoul National University in Korea, The University of Tokyo in Japan were studied.

\section{The Third Stage}

After summarizing and analyzing the results of the previous stages, the model was refined. At this stage, the researchers categorized different aspects and components of e-learning by summarizing the mutual concepts and related documents. The specific objectives were classified and presented to determine and understand the relevant concepts. Finally, a comprehensive model was presented. 


\section{Ethics Approval}

This study was approved by the Ethics Committee of the Virtual University of Medical Sciences. In this study, the following ethical issues were considered: This study was based solely on the data provided by specific websites, and the research literature and patients were not involved.

\section{FINDINGS}

The first specific objective of the study was to determine the components of the comprehensive model for designing e-learning in medical education. Through an extensive review of essential literature (87 selected papers examined over 7 months), we identified eight themes and 84 critial concepts of e-learning which can be classified as Necessity of reform in the Educational System, Factors contributing to the development of e-learning, The role of information and communication technology in medical education, Objectives of e-Learning, e-Learning Infrastructures, e-Learning barriers and limitations, Determinants of success in an e-learning system, Different forms of virtual institutes (Table 1).

Table. 1 Themes and Key concepts of e-learning in medical education

\begin{tabular}{|c|c|c|c|}
\hline & Them & Key Concepts & Authors, year \\
\hline 1 & $\begin{array}{l}\text { The necessity of } \\
\text { reform in } \\
\text { Educational } \\
\text { system }\end{array}$ & $\begin{array}{l}\text { The need to join the process of globalization, } \\
\text { Expanded educational opportunities and } \\
\text { educational justice, developing a new paradigm for } \\
\text { learning }\end{array}$ & $\begin{array}{l}\text { (Singh, 2018); (Collins \& Halverson, 2018); } \\
\text { (Brusamento, Kyaw, Whiting, Li, \& Tudor } \\
\text { Car, 2019) }\end{array}$ \\
\hline 2 & $\begin{array}{l}\text { Factors } \\
\text { contributing to } \\
\text { the development } \\
\text { of e-learning } \\
\text { in medical } \\
\text { education }\end{array}$ & $\begin{array}{l}\text { Technological advances, Entering the age of } \\
\text { information, changes in the demographic pattern, } \\
\text { decreased government fund for medical education, } \\
\text { competition in the educational market, a growing } \\
\text { trend of virtual learning in medical education }\end{array}$ & $\begin{array}{l}\text { (Garg \& Jain, 2017); (Bagrova, 2017); } \\
\text { (Hurtubise \& Roman, 2014); (Brusamento } \\
\text { et al., 2019) }\end{array}$ \\
\hline 3 & $\begin{array}{l}\text { The role of } \\
\text { information and } \\
\text { communication } \\
\text { technology } \\
\text { in medical } \\
\text { education }\end{array}$ & $\begin{array}{l}\text { Effect on educational curriculum } \\
\text { - Possibility to use an integrated curriculum } \\
\text { - Increasing importance and validity of curriculum } \\
\text { - Enhancing the accessibility of learners } \\
\text { - Imparting knowledge and clinical skills within an } \\
\text { appropriate structure } \\
\text { - Improving the usefulness of the educational } \\
\text { curriculum } \\
\text { - Enhancing student learning } \\
\text { - Curriculum flexibility } \\
\text { Evolution in learning } \\
\text { - Increasing learners' motivation } \\
\text { - Improving high-level reflection skills } \\
\text { - Time management and ability to prioritize basic } \\
\text { and clinical skills in an information atmosphere } \\
\text { - Creating liveliness } \\
\text { - Maintaining order in the class } \\
\text { - Improving medical skills and methods } \\
\text { - Cultivating learners' talents } \\
\text { - Creating a spirit of research } \\
\text { - Providing rapid feedback } \\
\text { - Decreasing anxiety } \\
\text { - Improving continuous professional development }\end{array}$ & $\begin{array}{l}\text { (Barclay, Donalds, \& Osei-Bryson, 2018); } \\
\text { (Cleveland \& Block, 2017); (Al-Emran, } \\
\text { Elsherif, \& Shaalan, 2016); (Horn \& Khalid, } \\
\text { n.d.)(Hamidi, Meshkat, Rezaee, \& Jafari, } \\
\text { 2011); (Bello et al., 2018); (Etzkowitz, } \\
\text { Webster, Gebhardt, \& Terra, 2000); } \\
\text { (Etzkowitz et al., 2000); (Hiltz \& Turoff, } \\
\text { 2005); (Allen \& Seaman, 2013); (A. R. } \\
\text { Brown \& Voltz, 2005); (Amin et al., 2018); } \\
\text { (M. Brown, Anderson, \& Murray, 2007); } \\
\text { (Marković, 2009); (Salimi et al., 2017); } \\
\text { (Talebian, Movahed Mohammadi, \& } \\
\text { Rezvanfar, 2014); (Whyte \& Hennessy, } \\
\text { 2017) }\end{array}$ \\
\hline
\end{tabular}


4 Objectives of e-Learning
Improving the quality and accessibility of educational opportunities regardless of time and place, acquiring competence, acquiring problemsolving skills, improving critical appraisal skills, improving clinical skills, management and decisionmaking in complex situations, lifelong learning, negotiating and establishing social relationships, valid scientific degrees
(Aboshady et al., 2015); (Gaupp et al., 2016); (Behnam, 2012); (Ellaway \& Masters, 2008); (De Leeuw et al., 2016); (Duncan, Miller, \& Jiang, 2012); ("The Priming Effects of Virtual Environments on Interpersonal Perceptions and Behaviors - Peña - 2013 Journal of Communication - Wiley Online Library," n.d.); (Aithal \& Aithal, 2015)

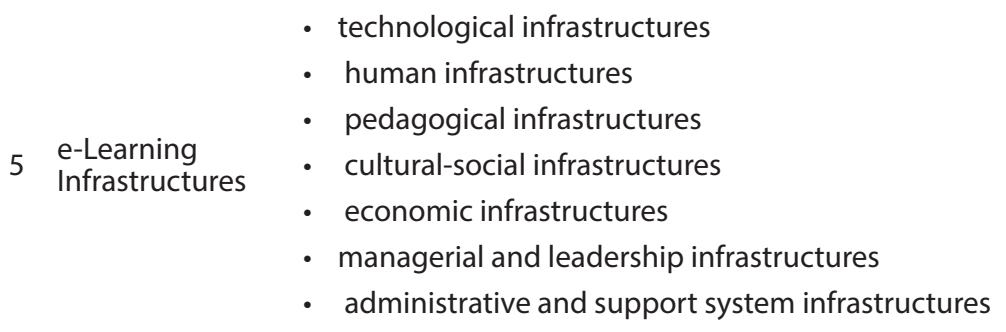

(Namisiko et al., 2014); (Marfo \& Kabutey Okine, n.d.); (Camelia \& Silviu, n.d.); (Oye, Salleh, \& lahad, 2011); (Mnyanyi \& Bakari, n.d.); (Ismail, Safieddine, \& Kulakli, 2018); (Cidral et al., 2018)
Instructors

- Limitations related to the competence of faculty members

- Lack of knowledge about virtual learning

- Lack of incentives

- Lack of ICT knowledge

- Lack of required educational skills

- Lack of innovation and research

- Instructors' unwillingness to cooperate in online courses

- Negative attitudes to virtual learning

Managers

- Lack of knowledge and insight among university and medical education officials

- Constraints in human resources and time

- Budget limitation

- Failure in change management

- Organizational structures and processes

e-Learning

6 barriers and limitations
- Managers' attitudes

- Educational costs

- Funding limitations

- Inadequate structural, political, and . organizational support

- Inadequate research and findings in this regard

Technological infrastructure

- Inadequate bandwidth

- Inadequate advanced systems for virtual learning

- Limitations in IT infrastructures

- Quality of online programs

Learners

- Improper evaluation methods in online education

- Lack of credit for virtual learning

- Lack of reliability and acceptability

- Absence of learning societies

- Inadequate student support services

- Poor quality of online content and courses

- Ambiguities in the roles of students and their capabilities
(Al-Ghaith, Sanzogni, \& Sandhu, 2010); (Tsai \& Chai, 2012) ("Overcoming barriers for eLearning in universities-portfolio models for competency development of faculty - Schneckenberg - 2010 - British Journal of Educational Technology - Wiley Online Library," n.d.); (Assareh \& Bidokht, 2011); (Franz et al., 2015); (Quadri et al., n.d.); (Idris \& Osman, 2016); (Quadri et al., n.d.); (Alshahrani, n.d.); (Qureshi, llyas, Yasmin, \& Whitty, n.d.); (Quadri et al., n.d.); (Afshari, Bakar, Luan, Samah, \& Fooi, 2009); ("Researching Learning in Virtual Worlds | Anna Peachey | Springer," n.d.) 


\begin{tabular}{|c|c|c|c|}
\hline 7 & $\begin{array}{l}\text { Determinants } \\
\text { of success of } \\
\text { e-learning } \\
\text { system }\end{array}$ & $\begin{array}{l}\text { - Interaction } \\
\text { - Learner-centeredness } \\
\text { - Attention to individual differences of learners } \\
\text { - Flexibility } \\
\text { - Encouraging active learning } \\
\text { - Use of IT capabilities } \\
\text { - Evaluation in all stages of learning } \\
\text { - Quality control }\end{array}$ & $\begin{array}{l}\text { (Ikram, Essink-Bot, \& Suurmond, 2015a); } \\
\text { (Ikram et al., 2015b); (Farajollahi, } \\
\text { Zare, \& Sarmadi, 2010); (Bhuasiri, } \\
\text { Xaymoungkhoun, Zo, Rho, \& Ciganek, } \\
\text { 2012); (Mosakhani \& Jamporazmey, } \\
\text { 2010); (Lwoga, 2014); (Ikram et al., 2015a); } \\
\text { (Whyte \& Hennessy, 2017); (Alhabeeb \& } \\
\text { Rowley, 2017); (Karanjam, Zarif Sanaiey, \& } \\
\text { Karanjam, 2017) }\end{array}$ \\
\hline 8 & $\begin{array}{l}\text { Different forms } \\
\text { of virtual } \\
\text { institutes }\end{array}$ & $\begin{array}{l}\text { Independent and joint distance learning centers } \\
\text { Virtual learning centers within an institution } \\
\text { Exclusive virtual learning centers } \\
\text { Corporate universities or private vocational centers } \\
\text { Virtual university consortiums }\end{array}$ & $\begin{array}{l}\text { (George et al., 2014); (Wingo, Ivankova, } \\
\text { \& Moss, 2017); (Ismail et al., 2018); (Fikile } \\
\text { \& Neil, 2017); (Malatji, 2017); (Ahmed } \\
\text { \& Elhag, 2017); (Aboshady et al., 2015); } \\
\text { (Arndt \& Guercio, 2017); (Pettersson \& } \\
\text { Olofsson, 2015) }\end{array}$ \\
\hline
\end{tabular}

Therefore, to design, stabilize, and enhance an e-Learning system, it is essential to consider the objectives, success determinants, barriers and limitations, infrastructures, and different forms of virtual institutes.

The second objective of the study was to determine and compare the structures of e-learning programs in medicine at renowned universities across the world for modeling based on the context of a country. The basics were studied in previous steps, and the objectives and executive strategies were investigated at this stage.

For that reason, the e-learning systems of some renowned universities in North America (13 universities), Europe (11 universities), and Asia (6 universities) were analyzed comparatively. In the first stage of the study, relevant and reliable information regarding the e-Learning systems of selected universities was documented. In the second and third stages, the documented information was critically analyzed and categorized to compare the similarities and differences between e-Learning programs. Finally, in the fourth stage, the best strategies for implementing e-Learning programs in Medical education were determined. Due to the lack of complete data available on university websites as well as overlapping and inadequate findings, some of the indicators were merged into more general categories (Table 2).

Table 2. Determination and comparison of the components of e-learning programs in well-known universities across the world

\begin{tabular}{|c|c|c|}
\hline Index & Comparative analysis of universities & $\begin{array}{l}\text { Appropriate strategies for } \\
\text { implementing e-Learning in } \\
\text { Medical Education }\end{array}$ \\
\hline \multirow{3}{*}{ Objective of e-Learning } & $\begin{array}{l}\text { In North America, the objective is to } \\
\text { receive a university degree in medical } \\
\text { sciences, especially at the Masters level and } \\
\text { sometimes Ph.D. }\end{array}$ & \multirow{3}{*}{$\begin{array}{l}\text { Designing appropriate } \\
\text { e-Learning systems based on } \\
\text { the target groups in medical } \\
\text { and interdisciplinary courses }\end{array}$} \\
\hline & $\begin{array}{l}\text { In Europe, virtual courses are offered for } \\
\text { empowerment, but equivalent degrees are } \\
\text { sometimes granted. A master's degree is } \\
\text { offered in some countries. }\end{array}$ & \\
\hline & $\begin{array}{l}\text { The situation is a little different in Asia. } \\
\text { Certificates are provided for primary and } \\
\text { competency courses, and few universities } \\
\text { admit students for Masters and Doctoral } \\
\text { levels. }\end{array}$ & \\
\hline Student admission criteria & $\begin{array}{l}\text { In all three continents, the applicants are } \\
\text { required to have a related degree. A CV } \\
\text { in North America and an oral and written } \\
\text { examination in Asia are also required. }\end{array}$ & $\begin{array}{l}\text { Determining suitable student } \\
\text { admission criteria }\end{array}$ \\
\hline
\end{tabular}




\begin{tabular}{|c|c|c|}
\hline Educational approach & $\begin{array}{l}\text { The educational approach is mostly blended } \\
\text { in North America and Europe, and virtual in } \\
\text { Asia. } \\
\text { In North America, various methods and } \\
\text { tools such as gamification, social networks } \\
\text { like Skype and Facebook, simulation and } \\
\text { webinar, video conferencing, and forums are } \\
\text { used. Social media are less frequently used } \\
\text { in Europe. Mobile learning is used in Asia } \\
\text { and North America while it is not popular } \\
\text { in Europe. In Asia, most presentations are in } \\
\text { the form of lectures that are lesson-driven. } \\
\text { Lectures are available in electronic format. }\end{array}$ & $\begin{array}{l}\text { Designing blended teaching- } \\
\text { learning approach (active and } \\
\text { interactive) }\end{array}$ \\
\hline Evaluation methods & $\begin{array}{l}\text { Although formative and summative } \\
\text { assessment methods are used in almost all } \\
\text { three continents, these methods are not } \\
\text { identical. In North America, projects and } \\
\text { peer assessment are of importance, while } \\
\text { journal writing, logbook, scientific bulletin, } \\
\text { portfolio, and individual and team projects } \\
\text { besides mutual assessment methods like } \\
\text { oral and written exams indicate the diversity } \\
\text { of assessment methods in Europe. Since } \\
\text { courses mostly aim at empowerment } \\
\text { in Asia, assessment is not usually done. } \\
\text { However, for academic majors, formative } \\
\text { and summative assessment methods are } \\
\text { used. }\end{array}$ & $\begin{array}{l}\text { Designing various methods for } \\
\text { evaluating students }\end{array}$ \\
\hline
\end{tabular}

Overall, the findings showed that in terms of providing virtual courses, The Australian National University, King's College, and Singapore University, were amongst the pioneers of this field. Given that one of the goals of establishing virtual universities is to create interdisciplinary courses to develop new ideas and identify existing issues, we decided to investigate the frequency of courses within the Medical field.

Amongst the Medical field, basic science, health, and nutrition, pharmacology and dentistry have entered into the area. In terms of developing interdisciplinary courses, mathematics, science, psychology, sociology, and technology have been integrated into the medical field and developed into new courses. Most of the offered courses have been delivered to Master's and in some cases Ph.D. students, indicating that the majority of courses are offered at the graduate level. Their educational strategies mostly comprise active learning approaches using both synchronous and asynchronous methods. Many online communication methods are suitable for developed countries with robust technological infrastructures. The implementation of e-learning in medical education in each of these settings is based on reliable infrastructures as well as executive, tactical, and strategic factors. We integrated the findings of stages 1 and 2 to present the following comprehensive model ( Figure 1). 


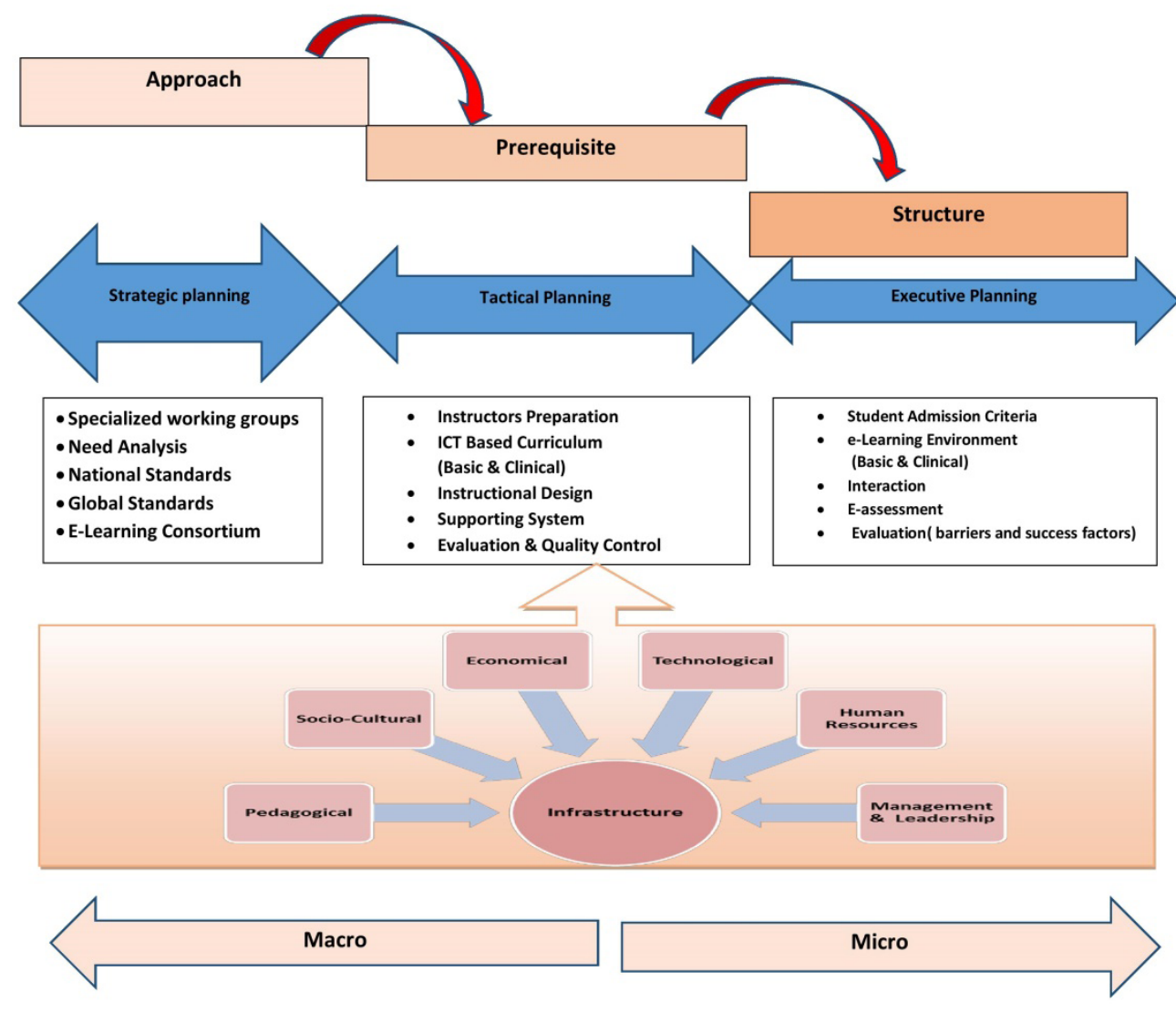

Figure.1 The Characteristics and Features of the comprehensive model for designing e-Learning in medical education

The proposed model is based on studies about different e-learning issues in medical education. It consists of four dimensions (approach, prerequisite, structure, and infrastructure). These dimensions and their fundamental concepts briefly include:

- Approach: In this dimension, strategic planning for achieving long-term goals is carried out. At this level, it is necessary to pass the required laws and determine the direction of managerial decisions in addition to the provision of infrastructures. This level is composed of the following categories; specific working group, need analysis, national standards, global standards, and e-Learning consortium. Therefore, a specialized working team is established to determine national and global standards, and by enforcing these standards in the context and local learning environment, the initial planning is performed. Moreover, an E-learning consortium will be finally formed for collaboration in providing quality e-learning resources and courses for medical education on national and international levels.

- Prerequisite: In this dimension, tactical planning and scheduling of short-term activities are required to achieve the objectives of strategic planning. In the tactical phase, attention should be paid to the preparation of instructors, recruitment of competent professors for curriculum design, integration of new technology infrastructures for the teaching-learning process, designing the supporting systems for learners and instructors, and applying measures for supervising and monitoring the quality of education.

- Structure: At this stage, such procedures as executive planning, student admission criteria, preparation of the proper educational content, application of suitable student assessment methods, adoption of various instructional and learner assessment methods, and evaluation of the programs are essential components of the structural dimension.

- Infrastructure: The model emphasizes the infrastructure of the educational system as a basis for designing medical education. Following this category, we need to establish the necessary infrastructure 
that is composed of: technical, pedagogical, sociocultural, and economic factors, along with human resources, management, and leadership.

- The ideal scenario of e-learning is to establish a university that is free from the limitations of traditional universities or regional restrictions. Therefore, the basis for the proposed model rests on the macro (international and national educational setting) and micro (learner, teacher, and teaching and learning processes) levels. While each level is discussed separately, in practice they are intimately connected.

\section{DISCUSSIONS AND CONCLUSION}

The present study aimed to develop a comprehensive model for designing e-learning in medical education. The model described here attempts to integrate all components of an educational system. The key dimensions of the model are the approach, prerequisite, structure, and infrastructure.

The Approach dimension is where the educational system determines the long-term goals, and performs strategic planning. In the Prerequisite dimension, tactical planning and scheduling of short-term activities are performed, and in the executive aspect, the teaching-learning process is planned.

We did not find any studies presenting a comprehensive model for e-learning in medical education; therefore, the findings of the following studies were compared with the studies that were somehow related to the main concepts of the present study. For example; Asgarimehr, Shirazi, Eskandari, \& Rostami (2012) developed a strategic framework for designing e-learning with a focus on university entrepreneurship. They found that the cooperation among officials in the government, industry, and educational system was essential in creating an entrepreneurial system. The results of these studies partly mirror the results of the present study; e-learning is not only adding a component to the educational system, but it is also an innovation in medical education. This innovation is a comprehensive part of the educational system (Ahmady, Kohan, Bagherzadeh, Rakshhani, \& Shahabi, 2018). Therefore in our model, we try to integrate e-learning in all aspects of medical education systems from the macro-level to the micro-level. At the macro-level, the focus is on the national and international settings of medical education and strategic planning, and at the microlevel, the focus is on the learner, design, implementation, and evaluation of learning environments such as medical schools and clinical settings.

Interaction with others is crucial for the gradual development of the learner's understanding. Interaction with human and non-human factors of the environment is an inevitable component of high-quality educational experiences (Aboshady et al., 2015). Some studies also examine the key success factors of an e-learning environment. For example, Basak, Wotto, \& Belanger (2016), studied the factors contributing to the success of e-learning from the perspectives of learners and teachers from four universities in the U.S., Mexico, Spain, and China. They concluded that from the learners' and instructors' points of view, essential factors in establishing an effective online program were course design, instruction, learning platform, interaction, learning content, and social presence.

M. Brown et al. (2007) identified critical elements of effective e-learning designs: providing interactive learning activities, creating motivation and enthusiasm in the learner, providing appropriate technologies for presentation, and learning within the social and personal context of the learner.

These studies were consistent with the findings of the present study. The results of our research indicated that e-learning programs at renowned universities applied collaborative methods including synchronous and asynchronous group forums, webinars, and virtual classes, as well as social networks. Moreover, one should consider the infrastructure when designing effective and interactive e-Learning. Thus, in our model, pedagogic, cultural, economic, and technological infrastructures are the basics for moving an active and interactive learning program into the operational stage.

Various factors affect the quality of an educational system. Evaluation of academic achievement is of paramount importance (Costello et al., 2014). The online assessment is rarely used in Summative evaluation, and as indicated by the results of this research, the selected universities used formative assessment methods such as seminar presentation, forum discussion, journal writing, logbook, electronic portfolio, self-assessment, peer reflection, case study, and peer assessment, in addition to summative evaluation, online testing, and in-person testing. The results of a study by Yerushalmy, Nagari-Haddif, \& Olsher (2017), showed that 
electronic evaluation is rarely used in the summative evaluation due to some obstacles like shortage of specialized facilities and difficulties in ensuring test security. Therefore, the present model covers a variety of assessment methods as an essential part of any educational learning process; assessment feedback should be employed to improve learning.

Also, the results of our study indicate that most countries are moving towards virtualization through the formation of consortiums. An e-Learning Consortium fosters inter-institutional collaboration and cooperation between organizations, institutes, and universities to create a synergistic environment. Establishing e-learning consortiums necessitates collaboration on national and international levels, which should be reflected in strategic planning.

In conclusion, meticulous attention should be paid to all aspects and elements of an e-Learning design before implementing it.

\section{LIMITATIONS AND FUTURE RESEARCH}

The main limitation of this study is that its findings cannot be extended to other fields, because the findings of the research are not tested to find out whether they are statistically significant or due to chance. In addition, only the available articles were reviewed and articles other than Farsi and English were excluded. However, there were no prior studies related to e-learning in medical education in the Iranian context. The findings of this study suggest that the criteria for designing E-Learning may not fully resolve the problem of its implementation. Other factors contributing to Structure are human resources and their role in implementing a successful e-Learning program. Additional studies are required to determine the validity of these findings. Using the above-mentioned criteria, researchers can develop a tool to measure the quality of this type of education. It will enable them to access varying levels of quality and determine further indexes.

Acknowledgements: The authors thank the Vice-chancellor of the Virtual University of Medical Sciences, Shiraz University of Medical Sciences, and Shahid Beheshti University of Medical Sciences for supporting this research. The authors also thank the Clinical Research Development Center of Shiraz University of Medical Sciences for the analysis.

\section{BIODATA and CONTACT ADDRESSES of AUTHORS}

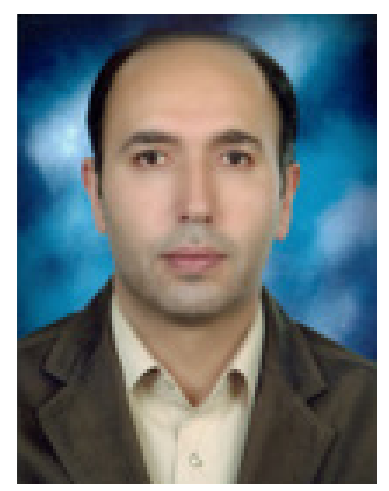

Dr. Soleiman AHMADY is an Associate Professor of Medical Education and Dean of Virtual School of Medical Education and Management at Shahid Beheshti University of Medical Sciences. Medical doctor and Ph.D. at Karolinska Institute, Sweden in Medical Educational at June 2008. His academic interest areas are clinical education, e-Learning, and simulation in medical education and distance learning. He has over 60 journal articles published in international indexes, 1 international book chapter, and other national and international articles, papers submitted to international meetings.

\section{Soleiman AHMADY}

Address: Velenjak St., Shahid Chamran Highway Shahid Beheshti University of Medical Sciences, Postal Code, 1985717443 Tehran.

Phone: +982122439982

Email:Intl_office@sbmu.ac.ir; soleiman.ahmady@gmail.com 


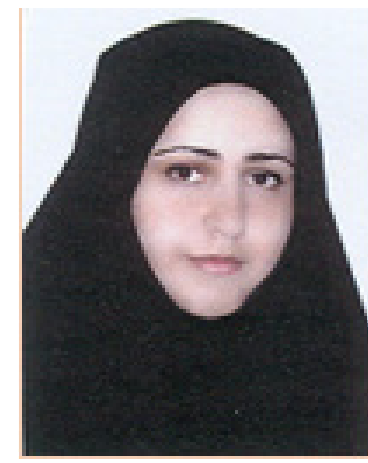

Dr. Zohrehsadat MIRMOGHTADAIE Is an Assistant Professor of e-learning in medical education at Shahid Beheshti University of Medical Sciences. She gained her Ph.D. In Medical Education in 2016. Her Academic Interest Areas Are Open and blended Learning, Medical Education Futures, E-Learning, and content production In Medical Education. She is head of the e-learning Department and has a lot of experience in content production.

\section{Zohrehsadat MIRMOGHTADAIE}

Address: Velenjak St., Shahid Chamran Highway Shahid Beheshti University of Medical Sciences, Postal Code, 1985717443 Tehran.

Phone: +989133294358

Email:mirmoghtada@sbmu.ac.ir; mirmoghtadaie@sina.tums.ac.ir

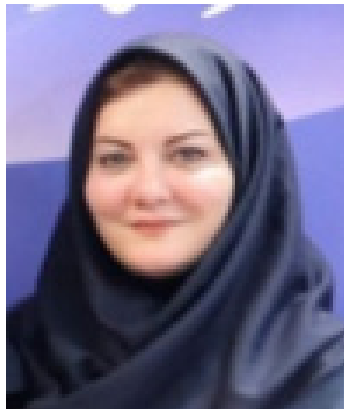

Dr. Nahid ZARIFSANAIEY is an Associate professor of the department of E-learning, Virtual School, and Comprehensive Center of Excellence for e-Learning in Medical Sciences. She lectures on e-learning concepts and principles, designs multimedia courses and supporting systems, conducts student evaluation, quality control, and assurance in e-learning subjects for graduate and postgraduate students of learning and medical education. She is also a director of many Master's and doctoral theses and has written several articles in international journals. Dr. Zarifsanaiey is interested in designing Ubiquitous and mobile environments in medical sciences, collaborative learning, patient education, simulation, and virtual patients.

Nahid ZARIFSANAIEY

Address: Virtual School and Center of Excellence in Electronic Learning, Neshat Ave., Postal Code 713451846, Shiraz, Iran.

Phone: +989177105042

E-mail: nzarifsanaee@gmail.com; sanaieyn@sums.ac.ir

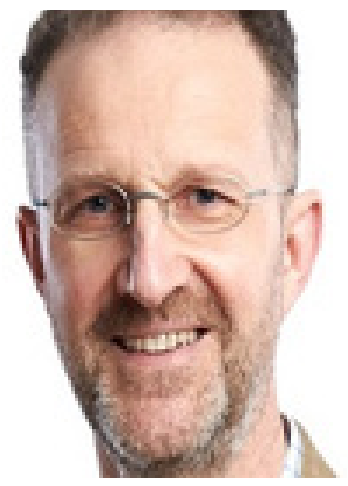

Dr. Johan THOR is an associate Professor of Social Medicine at the University of Jonkoping and also a scholar at Health Technology Assessment at the Stockholm regional health system. Dr. Thor gained his Ph.D. in Health Technology Assessment at Karolinska Institutet, Sweden.

Johan THOR

Academy for Improvement of Health and Welfare

Address: University of Jonkoping, Postal Code GA511, Jonkoping, Sweden

Phone: +460767881227

E-mail: johan.thor@ju.se 


\section{REFRENCES}

Aboshady, O. A., Radwan, A. E., Eltaweel, A. R., Azzam, A., Aboelnaga, A. A., Hashem, H. A., ... Afifi, A. M. (2015). Perception and use of massive open online courses among medical students in a developing country: multicentre cross-sectional study. BMJ Open, 5(1), e006804.

Aboumatar, H. J., Thompson, D., Wu, A., Dawson, P., Colbert, J., Marsteller, J., ... Pronovost, P. (2012). Development and evaluation of a 3-day patient safety curriculum to advance knowledge, selfefficacy and system thinking among medical students. BMJ Quality and Safety, 21(5), 416-422. https://doi.org/10.1136/bmjqs-2011-000463

Adick, C. (2018). Bereday and Hilker: origins of the 'four steps of comparison'model. Comparative Education, 54(1), 35-48.

Afshari, M., Bakar, K. A., Luan, W. S., Samah, B. A., \& Fooi, F. S. (2009). Factors affecting teachers' use of information and communication technology. International Journal of Instruction, 2(1).

Agarwal, S., \& Lenka, U. (2018). MANAGING ORGANIZATION EFFECTIVENESS THROUGH E-HUMAN RESOURCE MANAGEMENT TOOL-E-LEARNING: INDIAN CASES A QUALITATIVE APPROACH. PEOPLE: International Journal of Social Sciences, 4(1), 298-312. https://doi.org/10.20319/pijss.2018.41.298312

Ahmady, S., Kohan, N., Bagherzadeh, R., Rakshhani, T., \& Shahabi, M. (2018). Validity testing of classroom community scale in virtual environment learning: A cross sectional study. Annals of Medicine and Surgery, 36, 256-260.

Ahmed, A., \& Elhag, M. (2017). SMART KM model: The integrated knowledge management framework for organisational excellence. World Journal of Science, Technology and Sustainable Development, $14(2 / 3), 172-193$

Aithal, P. S., \& Aithal, S. (2015). An innovative education model to realize ideal education system. International Journal of Scientific Research and Management (IJSRM), 3(3), 2464-2469.

Al-Emran, M., Elsherif, H. M., \& Shaalan, K. (2016). Investigating attitudes towards the use of mobile learning in higher education. Computers in Human Behavior, 56, 93-102.

Al-Ghaith, W., Sanzogni, L., \& Sandhu, K. (2010). Factors influencing the adoption and usage of online services in Saudi Arabia. The Electronic Journal of Information Systems in Developing Countries, $40(1), 1-32$.

Alhabeeb, A., \& Rowley, J. (2017). Critical success factors for eLearning in Saudi Arabian universities. International Journal of Educational Management, 31(2), 131-147.

Allen, I. E., \& Seaman, J. (2013). Changing course: Ten years of tracking online education in the United States. ERIC.

Alshahrani, K. (n.d.). Teachers' Approaches and Conceptions of ICT in Teaching in Higher Education: CulturalHistorical View.

Amin, M. B., Joo, F. R., \& Jamali, A. (2018). Determining the Dimensions and Components of Elites Empowerment in Interaction with the Business Environment Based on Knowledge Economy and Technology. Interdisciplinary Journal of Virtual Learning in Medical Sciences, 9(3).

Arndt, T., \& Guercio, A. (2017). From Multimedia Micro-University to Macro University and beyond. Journal of Visual Languages \& Computing, 38, 38-46.

Asgarimehr, M., Shirazi, B., Eskandari, M. J., \& Rostami, S. (2012). A Strategic Framework for Designing E-Learning System with Focus on University Entrepreneurship. International Journal of Computer Science Issues (IJCSI), 9(1), 129.

Assareh, A., \& Bidokht, M. H. (2011). Barriers to e-teaching and e-learning. Procedia Computer Science, 3, 791-795. 
Bagrova, E. V. (2017). E-learning technologies in Yamalo-Nenets Autonomous Okrug. 2017 International Conference" Quality Management, Transport and Information Security, Information Technologies"(IT\&QQM\&IS), 625-627. IEEE.

Barclay, C., Donalds, C., \& Osei-Bryson, K.-M. (2018). Investigating critical success factors in online learning environments in higher education systems in the Caribbean. Information Technology for Development, 24(3), 582-611.

Basak, S. K., Wotto, M., \& Belanger, P. (2016). A framework on the critical success factors of e-learning implementation in higher education: A review of the literature. International Journal of Social, Behavioural, Economic, Business and Industrial Engineering, 10(7), 2259-2264.

Behnam, A. (2012). The Effect of information and communication technology on learning level, improvement of teaching-learning process and information literacy. Retrieved on June, 7, 2015.

Bello, G. A., Oludele, L. Y., \& Ademiluyi, A. B. (2018). IMPACT OF INFORMATION AND COMMUNICATION TECHNOLOGY ON TEACHING AND LEARNING. Nigerian Journal of Business Education (NIGJBED), 3(1), 201-209.

Bhuasiri, W., Xaymoungkhoun, O., Zo, H., Rho, J. J., \& Ciganek, A. P. (2012). Critical success factors for e-learning in developing countries: A comparative analysis between ICT experts and faculty. Computers \& Education, 58(2), 843-855.

Brown, A. R., \& Voltz, B. D. (2005). Elements of effective e-learning design. The International Review of Research in Open and Distributed Learning, 6(1).

Brown, M., Anderson, B., \& Murray, F. (2007). E-learning policy issues: Global trends, themes and tensions. ICT: Providing Choices for Learners and Learning. Proceedings Ascilite Singapore 2007.

Brusamento, S., Kyaw, B. M., Whiting, P., Li, L., \& Tudor Car, L. (2019, September 25). Digital Health Professions Education in the Field of Pediatrics: Systematic Review and Meta-Analysis by the Digital Health Education Collaboration. Journal of Medical Internet Research, Vol. 21, p. e14231. https://doi.org/10.2196/14231

Camelia, C., \& Silviu, C. (n.d.). IMPROVING THE LEARNING EXPERIENCE IN UNIVERSITIES BY USING COLLABORATION CLOUD-BASED IT SOLUTIONS. THE INTERNATIONAL CONFERENCE IN ECONOMICS AND ADMINISTRATION, 43.

Carnwell, R., \& Daly, W. (2001). Strategies for the construction of a critical review of the literature. Nurse Education in Practice, 1(2), 57-63.

Cidral, W. A., Oliveira, T., Di Felice, M., \& Aparicio, M. (2018). E-learning success determinants: Brazilian empirical study. Computers \& Education, 122, 273-290.

Cleveland, S., \& Block, G. (2017). Toward knowledge technology synchronicity framework for asynchronous environment. International Journal of Knowledge Society Research (IJKSR), 8(4), 23-33.

Collins, A., \& Halverson, R. (2018). Rethinking education in the age of technology: The digital revolution and schooling in America. Teachers College Press.

Costello, E., Corcoran, M. A., Barnett, J. S., Birkmeier, M. C., Cohn, R., Ekmekci, O., ... Robinson, S. (2014). Information and communication technology to facilitate learning for students in the health professions: Current uses, gaps, and future directions. Online Learning: Official Journal of the Online Learning Consortium, 18.

De Leeuw, R. A., Westerman, M., Nelson, E., Ket, J. C. F., \& Scheele, F. (2016). Quality specifications in postgraduate medical e-learning: an integrative literature review leading to a postgraduate medical e-learning model. BMC Medical Education, 16(1), 168.

Duncan, I., Miller, A., \& Jiang, S. (2012). A taxonomy of virtual worlds usage in education. British Journal of Educational Technology, 43(6), 949-964. 
Ellaway, R., \& Masters, K. (2008). AMEE Guide 32: e-Learning in medical education Part 1: Learning, teaching and assessment. Medical Teacher, 30(5), 455-473.

Etzkowitz, H., Webster, A., Gebhardt, C., \& Terra, B. R. C. (2000). The future of the university and the university of the future: evolution of ivory tower to entrepreneurial paradigm. Research Policy, 29(2), 313-330.

Farajollahi, M., Zare, H., \& Sarmadi, M. R. (2010). A CONCEPTUAL MODEL FOR EFFECTIVE DISTANCE LEARNING IN HIGHER EDUCATION. Turkish Online Journal of Distance Education-TOJDE.

Fernandez-Rodriguez, J. C. (2017). eLearning education. Psychol Cogn Sci Open J, 3(4), e14-e15.

Fikile, K. M., \& Neil, B. (2017). Perceptions of the Open Distance and E-Learning Model at a South African University. International Journal of Education and Practice, 5(8), 127-137. https://doi. org/10.18488/journal.61.2017.58.127.137

Franz, S., Behrends, M., Haack, C., \& Marschollek, M. (2015). Benefits and Barriers of E-Learning for Staff Training in a Medical University. ICIMTH, 99-102.

Frehywot, S., Vovides, Y., Talib, Z., Mikhail, N., Ross, H., Wohltjen, H., ... Scott, J. (2013). E-learning in medical education in resource constrained low-and middle-income countries. Human Resources for Health, 11(1), 4 .

Garg, R., \& Jain, D. (2017). Fuzzy multi-attribute decision making evaluation of e-learning websites using FAHP, COPRAS, VIKOR, WDBA. Decision Science Letters, 6(4), 351-364.

Garrison, D. R. (2011). E-learning in the 21st century: A framework for research and practice. Routledge.

Gaupp, R., Korner, M., \& Fabry, G. (2016). Effects of a case-based interactive e-learning course on knowledge and attitudes about patient safety: a quasi-experimental study with third-year medical students. BMC Medical Education, 16(1), 172. https://doi.org/10.1186/s12909-016-0691-4

George, P. P., Papachristou, N., Belisario, J. M., Wang, W., Wark, P. A., Cotic, Z., ... Car, J. (2014). Online eLearning for undergraduates in health professions: A systematic review of the impact on knowledge, skills, attitudes and satisfaction. Journal of Global Health, 4(1). https://doi. org/10.7189/jogh.04.010406

Haddad, W. D., \& Draxler, A. (2002). The dynamics of technologies for education. Academy for Educational Development, 2-17. Retrieved from http://www.estrategiaeducativa.com.mx/masterconsecuencias/ TechEdBook-1.pdf\#page $=29$

Hamidi, F., Meshkat, M., Rezaee, M., \& Jafari, M. (2011). Information technology in education. Procedia Computer Science, 3, 369-373. https://doi.org/10.1016/j.procs.2010.12.062

Hiltz, S. R., \& Turoff, M. (2005). Education goes digital: The evolution of online learning and the revolution in higher education. Communications of the ACM, Vol. 48, pp. 59-64. https://doi. org/10.1145/1089107.1089139

Horn, L. H., \& Khalid, M. S. (n.d.). Developing Creative Problem Solvers and Professional Identity through ICT in Higher Education. https://doi.org/10.4018/978-1-5225-0643-0.ch018

Hurtubise, L., \& Roman, B. (2014). Competency-based curricular design to encourage significant learning. Current Problems in Pediatric and Adolescent Health Care, 44(6), 164-169. https://doi. org/10.1016/j.cppeds.2014.01.005

Idris, F. A. A., \& Osman, Y. B. No Title. , Proceedings - 2015 5th International Conference on e-Learning, ECONF $2015 \$(2016)$.

Ikram, U. Z., Essink-Bot, M. L., \& Suurmond, J. (2015a). How we developed an effective e-learning module for medical students on using professional interpreters. Medical Teacher, 37(5), 422-427. https://doi.org/10.3109/0142159X.2014.939579 
Ikram, U. Z., Essink-Bot, M. L., \& Suurmond, J. No Title. , 37 Medical Teacher $\$(2015)$.

Ismail, R., Safieddine, F., \& Kulakli, A. No Title. , 2018-Janua Proceedings - 2017 International Conference on Engineering and MIS, ICEMIS $2017 \$(2018)$.

Karanjam, S. S., Zarif Sanaiey, N., \& Karanjam, S. (2017). Designing a Comprehensive Organizational E-Learning Model Using the Meta-Synthesis Method. Interdisciplinary Journal of Virtual Learning in Medical Sciences, In Press(In Press). https://doi.org/10.5812/ijvlms.11496

Lewis, K. O., Cidon, M. J., Seto, T. L., Chen, H., \& Mahan, J. D. (2014). Leveraging e-learning in medical education. Current Problems in Pediatric and Adolescent Health Care, 44(6), 150-163. https://doi. org/10.1016/j.cppeds.2014.01.004

Lwoga, E. T. (2014). Critical success factors for adoption of web-based learning management systems in Tanzania. In International Journal of Education and Development using Information and Communication Technology (IJEDICT) (Vol. 10).

Malatji, E. M. No Title. , 2017 8th International Renewable Energy Congress, IREC 2017 \$ (2017).

Marfo, J. S., \& Kabutey Okine, R. (n.d.). Implementation of e-Learning in Ghanaian Tertiary Institutions (A Case Study of KNUST).

Marković, M. R. (2009). Education through e-learning: Case of Serbia. Journal of Business Economics and Management, 10(4), 313-319. https://doi.org/10.3846/1611-1699.2009.10.313-319

Mnyanyi, C. B. F., \& Bakari, J. (n.d.). Implementing E-learning in Higher Open and Distance Learning Institutions in Developing Countries.

Mosakhani, M., \& Jamporazmey, M. No Title. , 1 ICEIT 2010 - 2010 International Conference on Educational and Information Technology, Proceedings S. (2010).

Namisiko, P., Munialo, C., \& Nyongesa, S. (2014). Towards an Optimization Framework for E-Learning in Developing Countries: A Case of Private Universities in Kenya. 2(2), 131-148.

Overcoming barriers for eLearning in universities-portfolio models for eCompetence development of faculty - Schneckenberg - 2010 - British Journal of Educational Technology - Wiley Online Library. (n.d.). Retrieved December 4, 2019, from https://onlinelibrary.wiley.com/doi/abs/10.1111/ j.1467-8535.2009.01046.x

Oye, N. D., Salleh, M., \& Iahad, N. A. (2011). CHALLENGES OF E-LEARING IN NIGERIAN UNIVERSITY EDUCATION BASED ON THE EXPERIENCE OF DEVELOPED COUNTRIES. International Journal of Managing Information Technology (IJMIT), 3(2). https:// doi.org/10.5121/ijmit.2011.3204

Pettersson, F., \& Olofsson, A. D. (2015). Implementing distance teaching at a large scale in medical education: A struggle between dominant and non-dominant teaching activities. Education and Information Technologies, 20(2), 359-380. https://doi.org/10.1007/s10639-013-9289-1

Quadri, N. N., Qureshi, M. N., Alsayed, A. O., Sanober, S., Naveed, Q. N., Rafik, M., ... Shah, A. (n.d.). Prioritizing barriers of E-Learning for effective teaching-learning using fuzzy analytic hierarchy process (FAHP) E-Learning CSFs and Barriers View project journal View project Prioritizing Barriers of E-Learning for Effective Teaching-Learning using Fuzzy Analytic Hierarchy Process (FAHP). https:// doi.org/10.1109/ICETAS.2017.8277855

Qureshi, I. A., Ilyas, K., Yasmin, R., \& Whitty, M. (n.d.). 310 Knowledge Management \& E-Learning. In An International Journal (Vol. 4).

Researching Learning in Virtual Worlds | Anna Peachey | Springer. (n.d.). Retrieved December 4, 2019, from https://www.springer.com/gp/book/9781849960465

Ruggie, J. G., University, H., USA, University, H., \& USA. (2017). The theory and practice of learning networks: corporate social responsibility and the Global Compact. 32-42. https://doi. org/10.4324/9781351281164-12 
Salimi, G., Mohammadi, M., \& Hosseini, N. (2017). Presenting a Framework for Effective E-Mentoring Relationships in Medical Sciences: A Meta-Synthesis Method. Interdisciplinary Journal of Virtual Learning in Medical Sciences, 8(4). https://doi.org/10.5812/ijvlms. 13860

Singh, A. (2018). Globalization of Education: E-Learning. International Journal of Indian Psychology, Volume 6, Issue 2,(No. 6), 6, 28.

Talebian, S., Movahed Mohammadi, H., \& Rezvanfar, A. (2014). Information and Communication Technology (ICT) in Higher Education: Advantages, Disadvantages, Conveniences and Limitations of Applying E-learning to Agricultural Students in Iran. Procedia - Social and Behavioral Sciences, 152, 300-305. https://doi.org/10.1016/j.sbspro.2014.09.199

The Priming Effects of Virtual Environments on Interpersonal Perceptions and Behaviors - Peña - 2013 Journal of Communication - Wiley Online Library. (n.d.). Retrieved December 4, 2019, from https://onlinelibrary.wiley.com/doi/abs/10.1111/jcom.12043

Tsai, C. C., \& Chai, C. S. (2012). The "third"-order barrier for technology-integration instruction: Implications for teacher education. Australasian Journal of Educational Technology, 28(6), 10571060. https://doi.org/10.14742/ajet.810

Whyte, W., \& Hennessy, C. (2017). Social Media use within medical education: A systematic review to develop a pilot questionnaire on how social media can be best used at BSMS. MedEdPublish, 6(2). https://doi.org/10.15694/mep.2017.000083

Willcocks, L. P., Sauer, C., \& Lacity, M. C. (2016). Enacting research methods in information systems: Volume 1. In Enacting Research Methods in Information Systems: Volume 1. https://doi.org/10.1007/978-3319-29266-3

Wingo, N. P., Ivankova, N. V, \& Moss, J. A. (2017). Faculty Perceptions about Teaching Online: Exploring the Literature Using the Technology Acceptance Model as an Organizing Framework. Online Learning, 21. https://doi.org/10.24059/olj.v21i1.761

Yerushalmy, M., Nagari-Haddif, G., \& Olsher, S. (2017). Design of tasks for online assessment that supports understanding of students' conceptions. ZDM - Mathematics Education, 49(5), 701-716. https:// doi.org/10.1007/s11858-017-0871-7 